\title{
Diagnosis of invasive candidiasis in the ICU
}

\author{
Philippe Eggimann ${ }^{1 *}$, Jacques Bille ${ }^{2}$ and Oscar Marchetti ${ }^{3}$
}

\begin{abstract}
Invasive candidiasis ranges from 5 to 10 cases per 1,000 ICU admissions and represents 5\% to 10\% of all ICU-acquired infections, with an overall mortality comparable to that of severe sepsis/septic shock. A large majority of them are due to Candida albicans, but the proportion of strains with decreased sensitivity or resistance to fluconazole is increasingly reported. A high proportion of ICU patients become colonized, but only 5\% to 30\% of them develop an invasive infection. Progressive colonization and major abdominal surgery are common risk factors, but invasive candidiasis is difficult to predict and early diagnosis remains a major challenge. Indeed, blood cultures are positive in a minority of cases and often late in the course of infection. New nonculture-based laboratory techniques may contribute to early diagnosis and management of invasive candidiasis. Both serologic (mannan, antimannan, and betaglucan) and molecular (Candida-specific PCR in blood and serum) have been applied as serial screening procedures in high-risk patients. However, although reasonably sensitive and specific, these techniques are largely investigational and their clinical usefulness remains to be established. Identification of patients susceptible to benefit from empirical antifungal treatment remains challenging, but it is mandatory to avoid antifungal overuse in critically ill patients. Growing evidence suggests that monitoring the dynamic of Candida colonization in surgical patients and prediction rules based on combined risk factors may be used to identify ICU patients at high risk of invasive candidiasis susceptible to benefit from prophylaxis or preemptive antifungal treatment.
\end{abstract}

\section{Epidemiology of invasive candidiasis}

Whereas in the past, opportunistic mycoses, such as Candida and Aspergillus, typically occurred in immunocompromised hosts, these complications are increasingly observed in nonimmunocompromised surgical and critically ill adult patients $[1,2]$. These trends were confirmed by a recent large international prevalence survey in ICUs, which reported infections due to Candida and Aspergillus in $17 \%$ and $1.4 \%$ patients, respectively [3].

\section{Incidence of candidemia}

A large epidemiological survey in the United States reported a threefold increase of fungal sepsis during the period 1979-2000, and candidemia was reported to be the third most common cause of nosocomial bloodstream infection (BSI) in critically ill adult patients, representing $11 \%$ of all BSI $[4,5]$. The incidence of candidemia in U.S. hospitals during 2000-2005 increased from 3.65 to 5.56 episodes per 100,000 population [6].

\footnotetext{
* Correspondence: philippe.eggimann@chuv.ch

${ }^{1}$ Adult Critical Care Medicine and Burn Centre, Centre Hospitalier Universitaire Vaudois (CHUV) - BH 08-619, Bugnon 46 CH-1011 Lausanne, Switzerland

Full list of author information is available at the end of the article
}

Incidences are usually tenfold higher in the ICUs than in other wards: 3 to 15 episodes per 10,000 ICU patients-days or 2 to 10 cases per 1,000 ICU admissions are reported, with highest rates among surgical patients $[1,7]$.

Data from Europe have shown that the incidence of candidemia may be lower, with proportions ranging from $2-3 \%$ of bloodstream isolates $[2,8]$. A recent national surveillance, including 2,820 cases of fungemia in Denmark during the period 2004-2009, reported an increasing incidence from 7.7 to 8.6 per 100,000 [9]. Despite important regional differences, these data show that Candida is among the top ten bloodstream pathogens and suggest an increasing incidence of candidemia during the past 5 to 10 years.

\section{Distribution of species}

A large geographical variation of the proportions of the different Candida species has been reported (Table 1) [2,7-16]. In North and South America, non-albicans Candida species account for more than half of the bloodstream isolates: C. glabrata and C. parapsilosis are the predominant non-albicans species, respectively. Whereas in Europe, C. albicans remains the most

\section{实}


Table 1 Distribution of Candida species in epidemiological surveys during the past decades

\begin{tabular}{|c|c|c|c|c|c|c|c|c|c|c|}
\hline Author & $\begin{array}{l}\text { Period of } \\
\text { observation }\end{array}$ & Study & Region & $\begin{array}{l}\text { No. of } \\
\text { strains }\end{array}$ & $\begin{array}{l}\text { Candida } \\
\text { albicans }\end{array}$ & $\begin{array}{l}\text { Candida } \\
\text { tropicalis }\end{array}$ & $\begin{array}{l}\text { Candida } \\
\text { parapsilosis }\end{array}$ & $\begin{array}{l}\text { Candida } \\
\text { glabrata }\end{array}$ & $\begin{array}{l}\text { Candida } \\
\text { krusei }\end{array}$ & $\begin{array}{l}\text { Other } \\
\text { Candida }\end{array}$ \\
\hline \multirow[t]{5}{*}{ Pfaller et al. [10] } & $2008-2009$ & SENTRY & Worldwide & $2^{\prime} 085$ & $48 \%$ & $11 \%$ & $17 \%$ & $18 \%$ & $2 \%$ & $4 \%$ \\
\hline & & & Europe & 750 & $55 \%$ & $7 \%$ & $14 \%$ & $16 \%$ & $3 \%$ & $4 \%$ \\
\hline & & & $\begin{array}{l}\text { North } \\
\text { America }\end{array}$ & 936 & $43 \%$ & $11 \%$ & $17 \%$ & $24 \%$ & $2 \%$ & $4 \%$ \\
\hline & & & $\begin{array}{l}\text { Latin } \\
\text { America }\end{array}$ & 348 & $44 \%$ & $17 \%$ & $26 \%$ & $5 \%$ & $1 \%$ & $5 \%$ \\
\hline & & & Asia & 51 & $57 \%$ & $12 \%$ & $14 \%$ & $14 \%$ & $2 \%$ & $2 \%$ \\
\hline Marra et al. [11] & $2007-2010$ & SCOPE & Brazil & 137 & $34 \%$ & $15 \%$ & $24 \%$ & $10 \%$ & $2 \%$ & $17 \%$ \\
\hline $\begin{array}{l}\text { Arendrup et al. } \\
\text { [9] }\end{array}$ & 2004-2007 & & Denmark & 2901 & $57 \%$ & $5 \%$ & $4 \%$ & $21 \%$ & $4 \%$ & $9 \%$ \\
\hline Horn et al. [12] & $2004-2008$ & PATH & $\begin{array}{l}\text { North } \\
\text { America }\end{array}$ & 2019 & $46 \%$ & $8 \%$ & $16 \%$ & $26 \%$ & $3 \%$ & $1 \%$ \\
\hline Leroy et al. [7] & $2005-2006$ & AmarCand & $\begin{array}{l}\text { France } \\
\text { ICU }\end{array}$ & 305 & $57 \%$ & $5 \%$ & $8 \%$ & $17 \%$ & $5 \%$ & $8 \%$ \\
\hline $\begin{array}{l}\text { Talarmin et al. } \\
\text { [13] }\end{array}$ & 2004 & & $\begin{array}{l}\text { France } \\
\text { West }\end{array}$ & 193 & $55 \%$ & $5 \%$ & $13 \%$ & $19 \%$ & $4 \%$ & $4 \%$ \\
\hline $\begin{array}{l}\text { Bougnoux et al. } \\
{[14]}\end{array}$ & $2001-2002$ & & $\begin{array}{l}\text { Paris } \\
\text { ICU }\end{array}$ & 57 & $54 \%$ & $9 \%$ & $14 \%$ & $17 \%$ & $4 \%$ & $2 \%$ \\
\hline $\begin{array}{l}\text { Marchetti et al. } \\
\text { [2] }\end{array}$ & $1991-2000$ & FUNGINOS & Switzerland & 1137 & $64 \%$ & $9 \%$ & $1 \%$ & $15 \%$ & $2 \%$ & $9 \%$ \\
\hline $\begin{array}{l}\text { Sandven et al. } \\
{[15]}\end{array}$ & 1991-2003 & & $\begin{array}{l}\text { Norway } \\
\text { Nationwide }\end{array}$ & 1393 & $70 \%$ & $7 \%$ & $6 \%$ & $13 \%$ & $1 \%$ & $3 \%$ \\
\hline Pfaller et al. [16] & 1997-2005 & ARTEMIS & Mondial ** & $55^{\prime} 229$ & $71 \%$ & $5 \%$ & $5 \%$ & $10 \%$ & $2 \%$ & $7 \%$ \\
\hline $\begin{array}{l}\text { Tortorano et al. } \\
\text { [8] }\end{array}$ & 1997-1999 & ECMM & Europe & 2089 & $52 \%$ & $7 \%$ & $13 \%$ & $13 \%$ & $2 \%$ & $13 \%$ \\
\hline
\end{tabular}

frequent species, epidemiological trends suggest that non-albicans Candida species, in particular C. glabrata, are emerging. In addition to differences in the fungal ecology of the different continents, the large use of azoles antifungal agents may have contributed to this progressive shift of the epidemiology of candidemia.

\section{Antifungal susceptibility}

Rates of reduced antifungal susceptibility or resistance ranging from $<5 \%$ to $>30 \%$ have been reported. The antifungal susceptibility of 2,085 Candida isolates to echinocandins (anidulafungin, micafungin) to new azoles (posaconazole, voriconazole) and to fluconazole were tested in the SENTRY survey according to the new Clinical and Laboratory Standard Institute (CLSI) breakpoints [10]. In C. albicans, no resistance to the five antifungals was observed. In contrast, resistance rates for C. glabrata were reported to be: fluconazole $5.6 \%$, posaconazole $3.7 \%$, voriconazole $3.5 \%$, anidulafungin $2.4 \%$, and micafungin $1.9 \%$, respectively. C. parapsilosis was found to be resistant to fluconazole in $5 \%$ of the isolates. C. tropicalis was resistant to fluconazole in $3.2 \%$ of isolates, to posaconazole in $0.9 \%$, and to voriconazole in $2.9 \%$. Finally, C. krusei was resistant in $2.5 \%$ of cases to voriconazole, whereas no resistance to posaconazole and to the two echinocandins was found. In
Denmark, the proportion of fully susceptible species decreased from $79.7 \%$ to $68.9 \%$ [9]. Leroy et al. reported a decreased susceptibility to fluconazole in $17 \%$ of isolates from 180 French ICUs [7].

\section{Selective pressure of antifungals on species distribution}

Preexposure to antifungals, such as prophylaxis, in particular with azoles, and to a lesser extent with echinocandins, has been associated with the occurrence of breakthrough infections with resistant Candida species. Whereas C. glabrata and C. krusei have been classically observed in these settings, other resistant non-albicans Candida species are being increasingly observed $[17,18]$. This was recently confirmed in a large prospective multicenter study conducted by the French Mycosis Study Group in 2,441 candidemic patients reporting that preexposure to fluconazole (159 episodes) or caspofungin (61 episodes) was associated with a higher proportion of less drugsusceptible C. glabrata or C. krusei (odds ratio (OR), 2.45; 95\% confidence interval (CI), 1.39-4.31) and C. parapsilosis, C. glabrata, or C. krusei (OR, 4.79; 95\% CI, 2.47-9.28), respectively [19]. These observations are not only of epidemiological interest, but the decreased in vitro antifungal susceptibility has been showed to be associated with increased morbidity and mortality in both immunocompromised and critically ill patients [7,20]. Monitoring of 
resistance plays an important role for updating treatment recommendations designed to improve patients' outcome.

\section{Impact of invasive candidiasis}

Candidemia typically occurs in colonized patients who accumulate other risk factors, such as major surgery, intravascular catheters, and antibacterial exposure, during a prolonged ICU stay $[1,21]$. It occurs at a median of 22 days after hospital admission compared with 13 days for Escherichia coli and 16 days for Staphylococcus aureus bacteremias according to the U.S. populationbased SCOPE study [5]. It occurred 14 (interquartile range, (IQR), 5-25) days and 19 ( \pm 3) days after ICU admission, in a survey of a university hospital from Paris and in the EPIC II study, respectively $[14,22]$.

Candidemia is associated with significant morbidity, which is reflected by a long ICU and hospital stay, ranging between one and several weeks $[7,14]$. The overall mortality in patients with invasive Candida infections is high: $42.6 \%$ in the EPIC II study [22]; 35.2\% at 12 weeks in the PATH study [12]; $37.9 \%$ in the ECMM study [8]; and $53.4 \%$ in non-ICU vs. $85.9 \%$ in ICU patients in the Brazilian SCOPE study [11]. In the PATH study, the highest mortality has been reported in C. krusei infections (52.9\%) and the lowest in C. parapsilosis infections (23.7\%), whereas intermediate rates were reported for $C$. albicans (35.6\%), C. glabrata (38.1\%), and C. tropicalis (41.1\%) [12]. Similar differences were found in the ECMM and the French surveys $[7,8]$. Significant differences in mortality in age groups also were reported: $16.8 \%$ in patients $0-19$ years of age, $31.3 \%$ in $19-65$ years of age, and $52.7 \%$ in > 65 years of age [12]. Mortality higher than $80 \%$ was reported in candidemic patients with septic shock [23]. The mortality attributable to candidemia ranged from 5 $49 \%$ according to the different types of studies (retrospective vs. prospective), patients (ICU vs. non-ICU, age), and healthcare settings $[8,24,25]$.

A substantial difference in mortality between patients who receive appropriate antifungal therapy $(<5 \%)$ and those without appropriate therapy (25-40\%) was observed in patients with septic shock [23]. Therapy of candidemia delayed beyond $12 \mathrm{~h}$ after sampling of blood has been associated with an increase of in-hospital mortality from $<20 \%$ to $40 \%[26,27]$. Because incubation accounts for the majority of the time elapsed between sampling of blood cultures and starting antifungal therapy, these data highlight the need for new noninvasive tools for anticipating diagnosis of invasive candidiasis in high-risk patients, which may play a key role for early and targeted empirical or preemptive treatment strategies [28-30].

\section{Pathogenesis of invasive candidiasis}

During past decades, many risk factors associated with the development of invasive candidiasis have been identified (Table 2) [21,31-33]. Among them, Candida colonization plays a key role in the pathogenesis of invasive candidiasis. Selective pressure trough antibacterial therapy alters the microbiota, resulting in overgrowth of Candida species on skin and mucosal surfaces [1]. Invasive procedures that disrupt natural skin or mucosal barriers, such as intravascular catheters, gastrointestinal tract surgery, and chemotherapy-associated mucositis, as well as decreased host defenses, in particular neutropenia, facilitate local invasion and further candidemia (Figure 1).

Host defenses against colonization of mucous membranes by Candida and invasion of tissues and/or dissemination via the bloodstream rely on distinct immunological mechanisms [34]. Recognition of fungi-associated molecular patterns involves several classes of pattern-recognition receptors. Toll-like receptors (TLRs) 2 and 4 recognize fungal cell-wall structures (mannans) and induce the production of proinflammatory cytokines [35]. Beta-1,3 glucans are sensed by dectin-1, a member of the C-type lectin family of receptors. Activation of the signal transduction pathways downstream of these receptors ultimately lead to the production of a complex array of mediators, including proinflammatory cytokines (such as TNF and IL-1) involved in adaptive immune response [36]. CD4+ T cells have been shown to play a critical role in host defenses against Candida infections. The interferon (IFN)- $\gamma$ mediated Th1 response stimulates the production of

\section{Table 2 Risk factors associated with the development of invasive candidiasis}

Colonization of several body sites
Broad-spectrum antibiotics
Immunosuppression
Neutropenia
Burns (> 50\%)
Disruption of physiological barriers in the digestive tract
Major abdominal surgery
Surgery of the urinary tract in presence of candiduria
Major trauma (ISS > 20)
Parenteral nutrition
Hemodialysis
APACHE score II > 20
Central venous catheter
Candiduria > $10^{5}$ cfu/ml
Young and old ages
Diabetes
Renal failure
Recent surgery
Urinary catheter
Vascular catheters
Prolonged ICU stay (> 7 days)
Multiple transfusions




\section{Owergrowth $\longleftarrow$ Modified microbiota $\downarrow$ \\ Mucosal colonization \\ Oro-pharyngeal \\ Upper + lower digestive tract Genital tract \\ Urinary tract

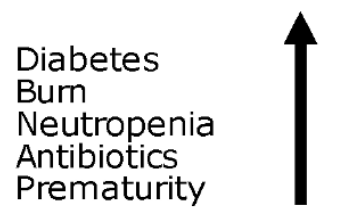

\section{Micro-invasion}

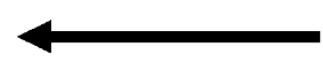

Multiple antibiotics

Vascular accesses

Parenteral nutrition

ICU stay $>7$ days

Candida colonization

Renal failure

Major abdominal surgery
Candidemia

Endopthalmitis
Endocarditis
Catheter-related
Abscess
CNS
Hepato-splenic

\section{Candidemia $\longrightarrow$ Disseminated disease}

Figure 1 Pathophysiology of invasive candidiasis.

specific anti-Candida immunoglobulins, whose role for prevention and clearance of infection remains to be elucidated [37]. These recent findings open new perspectives for identifying subgroups of patients at higher risk of developing invasive candidiasis and who may benefit from more specifically targeted preventive or preemptive antifungal strategies and/or of immunomodulating approaches [36].

\section{Diagnosis of candidiasis in critically ill patients}

Only $5-15 \%$ of patients are colonized by Candida spp. at ICU admission, but this proportion progressively increases with time to $50-80 \%$ as a result of prolonged exposure to many risk factors, such as major surgery, parenteral nutrition, dialysis, and antibiotics [33,38-40]. However, only $5-30 \%$ of colonized patients will develop invasive candidiasis, which is usually a late-onset ICU acquired infection $[7,14]$. As the clinical differentiation between colonized and infected critically ill patients remains difficult to assess, the utility and cost-effectiveness of colonization surveillance cultures remain unclear [41-43].

Two main types of Candida infections predominate. Candidemia occurs generally after several days or weeks of ICU stay, whereas Candida peritonitis more closely follows a complicated abdominal surgery. Conventional blood cultures, as well as cultures of other sterile body sites, albeit late and insensitive, remain the key diagnostic tools to identify Candida to the species level, and allow to test the activity of various antifungal agents.
Cultures from sites other than blood or normally sterile body fluids are nonspecific and reflect colonization in the majority of cases. Blood cultures become positive in a minority of patients with deep-seated candidiasis and often only late in the course of infection $[7,14,22]$. Conventional identification of Candida to the species level usually requires 1 to 3 days after detection of fungal growth in blood cultures. The recent development of new laboratory techniques (fluorescent in situ hybridization [FISH], and matrix-assisted laser desorption ionization time of flight mass-spectrometry [MALDITOF-MS]), significantly help to reduce the delay to species level identification, and thus allow an earlier choice of appropriate antifungal therapy [44].

Invasive candidiasis other than candidemia is difficult to diagnose. Clinical signs suggestive of invasive candidiasis did not differ from those of other nosocomial infections. More specific manifestations, such as retinal emboli (cotton whole) or hepatosplenic lesions are rare or only observed in cancer patients after neutrophils recovery $[45,46]$. Tissue sampling often requires invasive procedures at high risk of complications and has a low diagnostic yield, especially in patients who have received empirical therapy.

\section{Nonculture-based methods}

The delay between ICU admission and the occurrence of deep-seated Candida infections allows both to identify patients at increased risk and to attempt to detect early onset of infections. Several biomarkers are 
currently tested with this strategy, either based on antigen-antibody detection or on fungal DNA detection in serum or blood.

Commercially available antigen-based test target a Candida specific cell-wall component, mannan, or a nonspecific fungal element, beta-D-glucan. Both have a moderate sensitivity $(60 \%$ for mannan, $83 \%$ when combined to anti-mannan antibodies, $65-80 \%$ for beta-D-glucan) and are intended to be used as a screening strategy two to three times per week. Mostly tested in oncohematology patients, their value in an ICU population is still insufficiently documented $[47,48]$.

The second noncultural approach relies in detecting the presence of Candida DNA in the blood of at-risk patients. The major hurdle to this technique is the lack of commercial easy-to-use methods and the relative low sensitivity of this approach, due to several factors (low quantity of Candida cells in the blood, inhibitors due to blood cells). An additional difficulty is the "gold standard" generally used in evaluations, blood cultures, which itself lacks sensitivity. Available comparative studies in ICU patients are limited, showing a sensitivity equal to/or slightly lower than blood cultures (75-100\% compared with blood cultures) $[49,50]$.

\section{Clinical prediction of invasive candidiasis in critically ill patients}

Despite continuous progress and developments in this field, the absence of laboratory-based method currently available at the bedside has imposed pragmatic clinical approaches based on the appreciation of the dynamics of colonization and/or of the combination of less specific risk factors [51].

\section{Colonization-based assessment of the risk of invasive candidiasis}

Documentation of increasing amounts of Candida spp. in semiquantitative cultures from multiple sites has been found to predict the subsequent development of invasive candidiasis $[21,52,53]$. It has been suggested that the presence of Candida spp. in more than two body sites may justify the start of antifungal therapy $[54,55]$. However, critically ill patients are being colonized progressively during their ICU stay. The accuracy of a single-point assessment is low and such rule may be responsible for overuse of antifungals [56]. As initially proposed by Pittet et al. and confirmed by other investigators, a periodic evaluation of the dynamics of colonization in surgical patients at risk may predict more accurately the development of an invasive candidiasis [21,57-60].

In a prospective cohort study of surgical critically-ill patients, Pittet et al. assessed the degree of colonization by measuring daily the colonization index defined as the ratio of the number of distinct body sites colonized with genotypically identical strains of Candida over the total number of sites tested [21]. Eleven of 29 heavily colonized patients developed invasive candidiasis. The severity of the underlying conditions and the degree of colonization independently predicted the occurrence of invasive candidiasis. The average Candida colonization index was 0.47 for colonized vs. 0.7 for infected patients, respectively $(p<0.01)$. Furthermore, a threshold $\geq 0.5$ identified all infected patients at an average of 6 days before the diagnosis of invasive candidiasis.

The usefulness of the colonization index has never been demonstrated in a large prospective clinical trial, but its potential clinical value has been suggested in at least nine studies. Dubau et al. reported that an invasive candidiasis developed in only 1 of 35 surgical patients in whom empirical antifungals were prescribed when the index reached 0.5 and that it decreased rapidly in the 34 other patients [61]. Garbino et al. prospectively observed a decrease of the index in a group of critically ill patients receiving antifungal prophylaxis [42]. In contrast, it increased with time in those who received a placebo. Differences reached statistical significance between the two groups after 7 days. Chabasse et al. found a correlation between quantitative urine cultures above $10^{4} \mathrm{cfu} / \mathrm{mL}$ and a colonization index $\geq 0.5$ [62]. Charles et al. reported significantly higher values in medical patients $(0.74 \pm 0.31)$ compared with surgical patients $0.45 \pm 0.4(p=0.01)$ [57]. The index increased significantly by 0.1 during the ICU stay $(p=0.016)$ and the threshold of 0.5 was reached in 36 (39.1\%) of 92 nonsurgical ICU patients staying $>7$ days; 6 of them developed invasive candidiasis [63]. Hematological malignancy, duration of exposure to broad-spectrum antibiotics, fungal colonization at entry, and candiduria predicted an increase in the colonization index. In contrast, the duration of exposure to antifungals was significantly associated with its decrease. Compared with an historical cohort of 455 controls, the rate of invasive candidiasis decreased from $7 \%$ to $3.6 \%$ in a cohort of 478 surgical ICU patients who received preemptive antifungal treatment if the corrected colonization index was $>0.4$ [64]. This strategy avoided the development of ICU-acquired invasive candidiasis. Normand et al. reported a significant reduction of the colonization index in a cohort of 98 patients mechanically ventilated $>48$ hours randomized to receive prophylaxis by oral nystatin [65]. Agvald-Öhman et al. showed that increases of colonization index after major abdominal surgery were significantly correlated with the development of an IC [59]. Senn et al. reported a significant decrease of the colonization index in critically ill patients empirically treated with caspofungin after recurrent gastrointestinal perforation/anastomotic leakage or acute necrotizing pancreatitis [60].

Although these observations strongly suggests that the colonization index may be used to identify among 
colonized critically ill patients those who are susceptible to benefit from early initiation of antifungal therapy, this strategy is work-intensive, expensive, and difficult to implement on a routine basis at the bedside [66]. Its cost-effectiveness and usefulness for the management of critically ill patients remains to be proved in prospective comparative clinical trials [30]. In addition, limited data are available for nonsurgical patients.

\section{Risk of invasive candidiasis assessed by scores or predictive rules}

Scoring systems or predictive rules that combine clinical risk factors and information for Candida colonization have been recently proposed [67-69]. A risk-based "Candida score" has been developed by Leon et al. in a prospective cohort of 1,699 ICU patients staying more than 7 days [68]. Surgery (OR, 2.71; 95\% CI, 1.45-5.06), multifocal colonization (OR, 3.04; 95\% CI, 1.45-6.39), total parenteral nutrition (OR, 2.48; 95\% CI, 1.16-5.31), and severe sepsis (OR, 7.68; 95\% CI, 4.14-14.22) significantly predicted invasive candidiasis. By attributing one point of each risk factor, the score for a cutoff value of $2.5 \mathrm{had}$ a sensitivity and specificity of $81 \%$ and $74 \%$, respectively. The usefulness of this risk-factor based "Candida score" has been demonstrated further to rule out invasive candidiasis [70]. In a multicenter cohort of 1,007 patients staying for more than 7 days, only 13 of 565 (2.3\%) patients with a score $<3$ points developed a candidiasis, corresponding to a negative predictive value of $98 \%$. In this series, a linear progression of the risk of invasive candidiasis and higher score was further observed. The accuracy of a colonization index $\geq 0.5$ (relative risk, $5.98,95 \% \mathrm{CI}, 3.28$ 10.92) was lower than a Candida score $\geq 3$ (relative risk, 5.98; 95\% CI, 3.28-10.92).

Using a similar conceptual approach, Paphitou et al. identified retrospectively individual risk factors for the

Table 3 Criteria used for antifungal prophylaxis in adult critically ill patients

\begin{tabular}{|c|c|c|c|c|}
\hline Study & Criteria used for prophylaxis & $\begin{array}{l}\text { Antifungal used for } \\
\text { prophylaxis }\end{array}$ & $\begin{array}{l}\text { Invasive } \\
\text { candidiasis }\end{array}$ & Commentary \\
\hline \multicolumn{5}{|c|}{ Positive prophylactic studies } \\
\hline $\begin{array}{l}\text { *Slotman et } \\
\text { al. } \\
1987[77]\end{array}$ & $\begin{array}{l}\text { Abdominal surgery } \\
+\geq 3 \text { risk factors }\end{array}$ & $\begin{array}{l}\text { Ketoconazole } 200 \text { mg/d PO } \\
\text { Placebo }\end{array}$ & $\begin{array}{l}0 / 27(0 \%) \\
5 / 30(17 \%)^{+}\end{array}$ & $\begin{array}{l}\text { Costs: } \$ 4,800 \text { vs. } \$ 10,000^{\dagger} \\
\text { LOS: } 6.0 \text { vs. } 12.5 \text { days }^{\dagger}\end{array}$ \\
\hline $\begin{array}{l}\text { *Savino et al. } \\
1992 \text { [78] }\end{array}$ & $\begin{array}{l}\text { Surgical patients } \\
+ \text { hypermetabolism }\end{array}$ & $\begin{array}{l}\text { Nystatin/norfloxacin PO } \\
\text { Placebo }\end{array}$ & $\begin{array}{l}6 / 25(24 \%) \\
13 / 21(62 \%)^{\ddagger}\end{array}$ & $\begin{array}{l}\text { NI per patient: } \\
0.9 \text { vs. } 2.0^{\dagger}\end{array}$ \\
\hline $\begin{array}{l}\text { Desai et al. } \\
1992 \text { [79] }\end{array}$ & Severely burned patients & $\begin{array}{l}\text { Nystatin/polymyxin SDD } \\
\text { No prophylaxis }\end{array}$ & $\begin{array}{l}34 / 1042(3.3 \%) \\
0 / 1439(0 \%)^{+}\end{array}$ & $\begin{array}{l}\text { Superficial infections: } \\
59(21 \%) \text { vs. } 22(10 \%)^{+}\end{array}$ \\
\hline $\begin{array}{l}\text { Eggimann et } \\
\text { al. } \\
1999[39] *\end{array}$ & $\begin{array}{l}\text { Abdominal surgery } \\
+ \text { tertiary peritonitis }\end{array}$ & $\begin{array}{l}\text { Fluconazole } 400 \text { mg/d IV } \\
\text { Placebo }\end{array}$ & $\begin{array}{l}1 / 23(9 \%) \\
7 / 20(35 \%)^{\ddagger}\end{array}$ & $\begin{array}{l}\text { Candida peritonitis } \\
1(4 \%) \text { vs. } 7(35 \%)^{\dagger}\end{array}$ \\
\hline $\begin{array}{l}\text { Pelz et al. } \\
2001[43]^{*}\end{array}$ & $\begin{array}{l}\text { Surgical patients } \\
+ \text { LOS }>3 \text { days }\end{array}$ & $\begin{array}{l}\text { Fluconazole } 400 \text { mg/d PO } \\
\text { Placebo }\end{array}$ & $\begin{array}{l}11 / 130(8 \%) \\
20 / 130(15 \%)^{\dagger}\end{array}$ & $>75 \%$ colonized at randomization \\
\hline $\begin{array}{l}\text { Garbino et al. } \\
2002[42]^{*}\end{array}$ & Mechanically ventilated $>96 \mathrm{~h}$ & $\begin{array}{l}\text { Fluconazole } 100 \mathrm{mg} \mathrm{PO} \mathrm{+} \\
\text { SDD } \\
\text { Placebo + SDD }\end{array}$ & $\begin{array}{l}4 / 103(4 \%) \\
10 / 101(10 \%)^{\ddagger}\end{array}$ & 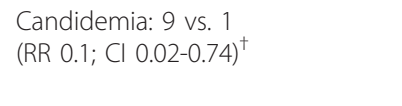 \\
\hline $\begin{array}{l}\text { Jacobs et al. } \\
2003[80] *\end{array}$ & $\begin{array}{l}\text { ICU } \\
+ \text { septic shock }\end{array}$ & $\begin{array}{l}\text { Fluconazole } 200 \mathrm{mg} \mathrm{IV/d} \\
\text { Placebo }\end{array}$ & $\begin{array}{l}0 / 32(0 \%) \\
1 / 39(3 \%)^{\ddagger}\end{array}$ & $\begin{array}{l}\text { Mortality significantly reduced in } \\
\text { peritonitis }\end{array}$ \\
\hline $\begin{array}{l}\text { He et al. } \\
2003[81]\end{array}$ & Severe acute pancreatitis & $\begin{array}{l}\text { Fluconazole } 100 \mathrm{mg} \mathrm{IV/d} \\
\text { Placebo }\end{array}$ & $\begin{array}{l}2 / 22(9 \%)^{+} \\
7 / 23(30 \%)^{+}\end{array}$ & $\begin{array}{l}\text { Mortality 2/2 (100\%) } \\
\text { Mortality 3/7 (43\%) }\end{array}$ \\
\hline \multicolumn{5}{|c|}{ Negative prophylactic studies } \\
\hline $\begin{array}{l}\text { Savino et al. } \\
1994[78]\end{array}$ & $\begin{array}{l}\text { Surgical patients } \\
+ \text { LOS }>2 \text { days }\end{array}$ & $\begin{array}{l}\text { Nystatin } 2 \times 10^{6} 4 \times / \mathrm{d} \text { PO } \\
\text { Ketoconazole } 200 \mathrm{mg} / \mathrm{d} \text { PO } \\
\text { Clotrimazole } 10 \mathrm{mg} 3 \times / \mathrm{d} \text { PO } \\
\text { No prophylaxis }\end{array}$ & $\begin{array}{l}5 / 75(7 \%) \\
1 / 65(2 \%)^{\ddagger} \\
1 / 80(1 \%)^{\ddagger} \\
2 / 72(3 \%)^{\ddagger}\end{array}$ & \\
\hline $\begin{array}{l}\text { Ables et al. } \\
2000[82]^{*}\end{array}$ & $\begin{array}{l}\text { Surgical patients } \\
+ \text { LOS }>2 \text { days }+ \text { other risk factors }\end{array}$ & $\begin{array}{l}\text { Fluconazole } 3 \mathrm{mg} / \mathrm{kg} 3 \times / \mathrm{w} \\
\text { Placebo }\end{array}$ & $\begin{array}{l}8 / 60(13 \%) \\
11 / 59(19 \%)^{\ddagger}\end{array}$ & \\
\hline $\begin{array}{l}\text { Sandven et } \\
\text { al. } \\
2002[40]^{*}\end{array}$ & Surgery for peritonitis & $\begin{array}{l}\text { Fluconazole } 400 \text { mg/d IV } \\
\text { Placebo }\end{array}$ & $\begin{array}{l}- \\
-\end{array}$ & $\begin{array}{l}\text { Mortality rates NS } \\
4 / 53(8 \%) \text { vs. } 8 / 56(14 \%)\end{array}$ \\
\hline $\begin{array}{l}\text { Schuster et } \\
\text { al. } \\
2008[83]^{*}\end{array}$ & $\begin{array}{l}\text { ICU } \geq 4 \mathrm{~d} \\
+ \text { Fever }>4 \mathrm{~d} \text { under broad-spectrum } \\
\text { antibiotics } \\
+ \text { APACHE } \| \geq 16\end{array}$ & $\begin{array}{l}\text { Fluconazole } 400 \text { mg/d IV } \\
\text { Placebo }\end{array}$ & $\begin{array}{l}6 / 122(5 \%) \\
11 / 127(9 \%)^{\ddagger}\end{array}$ & \\
\hline
\end{tabular}

*Prospective randomized double-blind

${ }^{+} \mathrm{p}<0.05$

${ }^{\ddagger}$ Not significant 
development of invasive candidiasis in a cohort of 327 surgical ICU patients to build a predictive rule [71]. The rate of invasive candidiasis was $17 \%$ for patients staying more than 3 days in ICU, with the combination of diabetes mellitus, dialysis, total parenteral nutrition, and exposure to broad-spectrum antibiotics compared with $5 \%$ for those lacking these characteristics $(p<0.01)$. Fifty-two percent of patients met this rule, which captured $78 \%$ of those who developed invasive candidiasis. For patients staying 4 days or more, Ostrosky-Zeichner et al. refined this preliminary clinical prediction rule in a large multicenter retrospective study [72]. Any systemic antibiotics or the presence of a central venous catheter during the 3 preceding days and at least two of the preceding risk factors was able to identify patients with a risk of invasive candidiasis of at least $10 \%$. However, with a sensitivity of $34 \%$ this rule captured only one third of cases of invasive candidiasis. The usefulness of a risk-factors-based predictive rule has been suggested in a medical ICU where antifungals were empirically prescribed accordingly [73]. Thirty-six (2.6\%) of all patients admitted received antifungals empirically, allowing a significant decrease of the rate of fungal catheter-related bloodstream infections from 3.4 to 0.79 episodes per 1,000 catheter-days. The sensitivity of such clinical predictive rule was markedly improved (66\%) with a maintained specificity ( $87 \%$ ) by taking into account the presence of Candida colonization at time of its assessment [74]. This new rule is currently investigated in a randomized, placebo-controlled, pilot study on empirical therapy with caspofungin in high-risk ICU patients (MSG-04 in mixed patients, INTENSE study in surgical patients, http://www.clinicaltrials.gov).

However, the common characteristics of risk scores and clinical rules is not their relatively low positive predictive value for diagnosing invasive candidiasis but their high negative predictive value for ruling out infection. This may allow withholding a number of unnecessary antifungal treatments in critically ill patients.

\section{Management of invasive candidiasis in critically ill} patients

Rapid initiation of appropriate antifungal therapy has been shown to reduce mortality in patients with candidemia $[24,75]$. Prophylaxis should strongly be restricted to very specific subgroups of patients in whom it has been demonstrated to be useful (Table 3). Preemptive therapy for colonized patients or those with high-risk scores and empirical therapy in septic patients not responding to appropriate antibacterial treatment are possible early interventions (Figure 2) [28,60].

\section{Practical approach to early diagnosis of invasive} candidiasis in critically ill patients

Although recognized as a strong risk factor, colonization, which may occur early after ICU admission, does not justify the start of empirical antifungal treatment [76]. Despite promising preliminary results, biomarkers are currently only available for research purpose. Accordingly, clinicians should continue to combine risk factors and the dynamic of colonization to try to identify

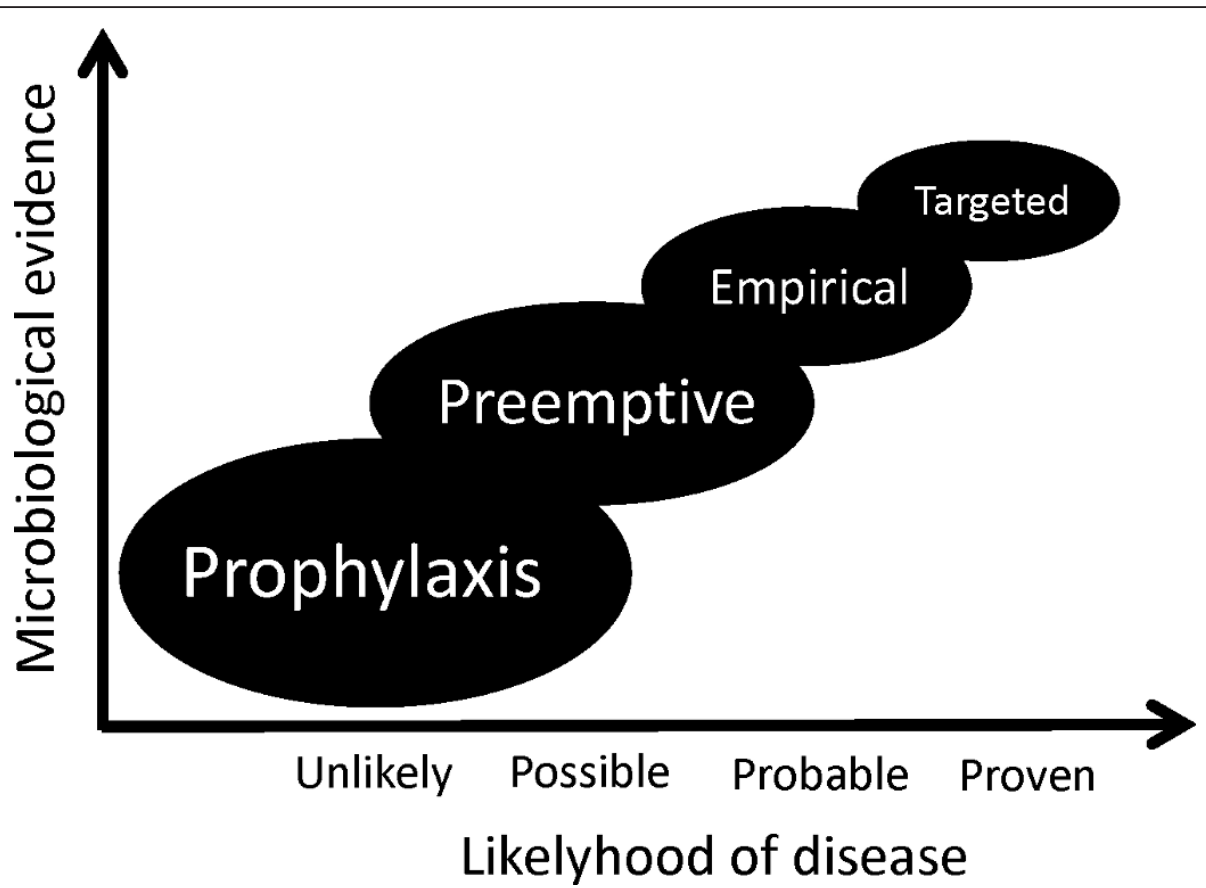

Figure 2 Concept of antifungal treatments in critically ill patients. 


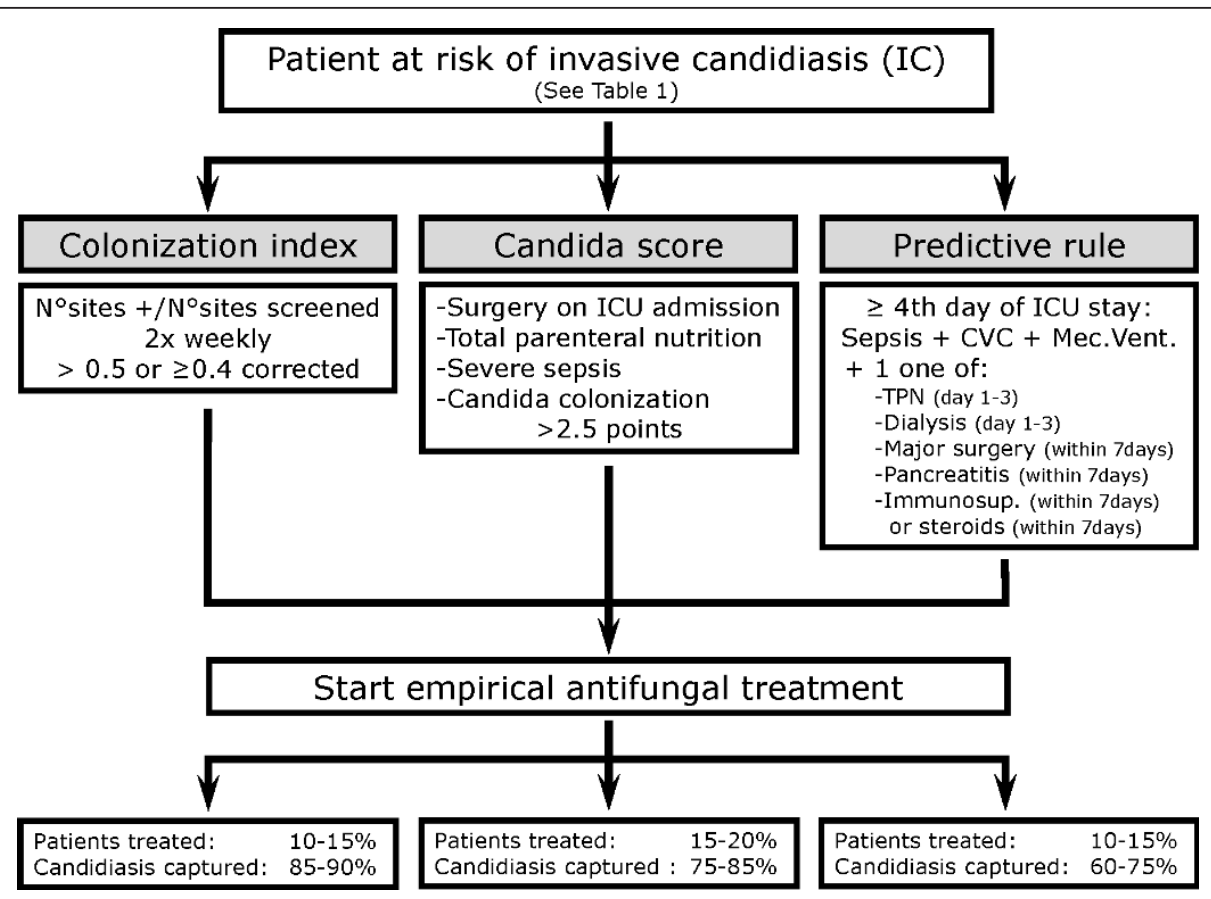

Figure 3 Practical approach of patient at risk of invasive candidiasis. Suggested algorithm to be applied in patients at risk of invasive candidiasis after having check that they are among those susceptible to benefit from prophylaxis (see Table 3) or evaluated to be at a risk level too low to justify antifungal prophylaxis, such as early after extended abdominal surgery or secondary peritonitis.

early critically ill patients susceptible to benefit from early empirical antifungal treatment (Figure 3 ).

\section{Author details}

${ }^{1}$ Adult Critical Care Medicine and Burn Centre, Centre Hospitalier Universitaire Vaudois (CHUV) - BH 08-619, Bugnon 46 CH-1011 Lausanne, Switzerland ${ }^{2}$ Institute of Microbiology, Centre Hospitalier Universitaire Vaudois (CHUV), Lausanne, Switzerland ${ }^{3}$ Infectious Diseases Service, Centre Hospitalier Universitaire Vaudois (CHUV), and University of Lausanne (UNIL), Lausanne, Switzerland

\section{Authors' contributions}

$P E, J B$ and $O M$ designed the structure of this review, wrote dedicated original sections and contributed to finalize MS.

\section{Competing interests}

Pertinent to this article, PE received research grants and/or educational grants and/or speaker's honoraria and/or consultant's honoraria's from the (in alphabetic order): Astellas, Merck, Sharp \& Dohme-Chibret, and Pfizer. JB has no disclosures regarding this manuscript. OM received unrestricted research grants and/or educational grants and/or speaker's honoraria and/or consultant's honoraria from (in alphabetical order): Foundation for the Advancement in Medical Microbiology and Infectious Diseases FAMMID, Associates of Cape Code, BioMérieux-Cepheid, Bio-Rad, Essex Schering-Plough, Gilead, Merck, Sharp \& Dohme-Chibret, Novartis, Pfizer, Roche Diagnostics, Wako.

Received: 6 July 2011 Accepted: 1 September 2011 Published: 1 September 2011

\section{References}

1. Eggimann P, Garbino J, Pittet D: Epidemiology of Candida species infections in critically ill non-immunosuppressed patient. Lancet Infect Dis 2003, 3:685-702.
2. Marchetti O, Bille J, Fluckiger U, Eggimann $P$, Ruef C, Calandra T, et al: Epidemiology of candidemia in Swiss tertiary care hospitals: secular trends 1991-2000. Clin Infect Dis 2004 38:311-320.

3. Vincent JL, Rello J, Marshall J, Silva E, Anzueto A, Martin CD, et al: International study of the prevalence and outcomes of infection in intensive care units. JAMA 2009, 302:2323-2329.

4. Martin GS, Mannino DM, Eaton S, Moss M: The epidemiology of sepsis in the United States from 1979 through 2000. N Engl J Med 2003, 348:1546-1554.

5. Wisplinghoff $H$, Bischoff $T$, Tallent SM, Seifert H, Wenzel RP, Edmond MB: Nosocomial bloodstream infectionsin US hospitals: analysis of 24,179 cases from a prospective nationwidestudy. Clin Infect Dis 2004, 39:309-317.

6. Zilberberg MD, Shorr AF, Kollef MH: Secular trends in candidemia-related hospitalization in the United States, 2000-2005. Infect Control Hosp Epidemiol 2008, 29:978-980.

7. Leroy O, Gangneux JP, Montravers P, Mira JP, Gouin F, Sollet JP, et al: Epidemiology, management, and risk factors for death of invasive Candida infections in critical care: a multicenter, prospective, observational study in France (2005-2006). Crit Care Med 2009, 37:1612-1618.

8. Tortorano AM, Kibbler C, Peman J, Bernhardt H, Klingspor L, Grillot R: Candidaemia in Europe: epidemiology and resistance. Int J Antimicrob Agents 2006, 27:359-366.

9. Arendrup MC, Bruun B, Christensen JJ, Fuursted K, Johansen HK, Kjaeldgaard $P$, et al: National surveillance of fungemia in Denmark (2004 to 2009). J Clin Microbiol 2011, 49:325-334.

10. Pfaller MA, Moet GJ, Messer SA, Jones RN, Castanheira M: Geographic variations in species distribution and echinocandin and azole antifungal resistance rates among Candida bloodstream infection isolates: report from the SENTRY Antimicrobial Surveillance Program (2008 to 2009). J Clin Microbiol 2011, 49:396-399.

11. Marra AR, Camargo LF, Pignatari AC, Sukiennik T, Behar PR, Medeiros EA et al: Nosocomial bloodstream infections in Brazilian hospitals: analysis of 2,563 cases from a prospective nationwide surveillance study. J Clin Microbiol 2011, 49:1866-1871. 
12. Horn DL, Neofytos D, Anaissie EJ, Fishman JA, Steinbach WJ, Olyaei AJ, et al: Epidemiology and outcomes of candidemia in 2019 patients: data from the prospective antifungal therapy alliance registry. Clin Infect Dis 2009, 48:1695-1703.

13. Talarmin JP, Boutoille $D$, Tattevin $P$, Dargere $S$, Weinbreck $P$, Ansart $S$, et al: [Epidemiology of candidemia: a one-year prospective observational study in the west of France]. Med Mal Infect 2009, 39:877-885.

14. Bougnoux ME, Kac G, Aegerter P, d'Enfert C, Fagon JY: Candidemia and candiduria in critically ill patients admitted to intensive care units in France: incidence, molecular diversity, management and outcome. Intensive Care Med 2008, 34:292-299.

15. Sandven P, Bevanger L, Digranes A, Haukland HH, Mannsaker T, Gaustad P: Candidemia in Norway (1991 to 2003): results from a nationwide study. J Clin Microbiol 2006, 44:1977-1981.

16. Pfaller MA, Diekema DJ, Gibbs DL, Newell VA, Meis JF, Gould IM, et al: Results from the ARTEMIS DISK Global Antifungal Surveillance study, 1997 to 2005: an 8.5-year analysis of susceptibilities of Candida species and other yeast species to fluconazole and voriconazole determined by CLSI standardized disk diffusion testing. J Clin Microbiol 2007, 45:1735-1745.

17. Hachem R, Hanna H, Kontoyiannis D, Jiang Y, Raad I: The changing epidemiology of invasive candidiasis: candida glabrata and Candida krusei as the leading causes of candidemia in hematologic malignancy. Cancer 2008, 112:2493-2499.

18. Sipsas NV, Lewis RE, Tarrand J, Hachem R, Rolston KV, Raad II, et al: Candidemia in patients with hematologic malignancies in the era of new antifungal agents (2001-2007): stable incidence but changing epidemiology of a still frequently lethal infection. Cancer 2009, 115:4745-4752.

19. Lortholary O, Desnos-Ollivier M, Sitbon K, Fontanet A, Bretagne S, Dromer F: Recent exposure to caspofungin or fluconazole influences the epidemiology of candidemia: a prospective multicenter study involving 2,441 patients. Antimicrob Agents Chemother 2011, 55:532-538.

20. Viscoli C, Girmenia C, Marinus A, Collette L, Martino P, Vandercam B, et al: Candidemia in cancer patients: a prospective, multicenter surveillance study by the Invasive Fungal Infection Group (IFIG) of the European Organization for Research and Treatment of Cancer (EORTC). Clin Infect Dis 1999, 28:1071-1079

21. Pittet D, Monod M, Suter PM, Frenk E, Auckenthaler R: Candida colonization and subsequent infections in critically ill surgical patients. Ann Surg 1994, 220:751-758.

22. Kett DH, Azoulay E, Echeverria PM, Vincent JL: Candida bloodstream infections in intensive care units: Analysis of the extended prevalence of infection in intensive care unit study. Crit Care Med 2011, 39:665-670.

23. Kumar A, Ellis $P$, Arabi $Y$, Roberts $D$, Light B, Parrillo JE, et al: Initiation of inappropriate antimicrobial therapy results in a fivefold reduction of survival in human septic shock. Chest 2009, 136:1237-1248.

24. Zaoutis TE, Argon J, Chu J, Berlin JA, Walsh TJ, Feudtner C: The epidemiology and attributable outcomes of candidemia in adults and children hospitalized in the United States: a propensity analysis. Clin Infect Dis 2005, 41:1232-1239.

25. Gudlaugsson O, Gillespie S, Lee K, Vande BJ, Hu J, Messer S, et al: Attributable mortality of nosocomial candidemia, revisited. Clin Infect Dis 2003, 37:1172-1177.

26. Morrell M, Fraser V, Kollef MH: Delaying the empiric treatment of Candida bloodstream infection until positive blood culture results are obtained: a potential risk factor for hospital mortality. Antimicrob Agents Chemother 2005, 39:3640-3645.

27. Garey KW, Rege M, Pai MP, Mingo DE, Suda KJ, Turpin RS, et al: Time to initiation of fluconazole therapy impacts mortality in patients with candidemia: a multi-institutional study. Clin Infect Dis 2006, 43:25-31.

28. Playford EG, Eggimann P, Calandra T: Antifungals in the ICU. Curr Opin Infect Dis 2008, 21:610-619.

29. Pappas PG, Kauffman CA, Andes D, Benjamin DK Jr, Calandra TF, Edwards JE $\mathrm{Jr}$, et al: Clinical practice guidelines for the management of candidiasis: 2009 update by the Infectious Diseases Society of America. Clin Infect Dis 2009, 48:503-535.

30. Eggimann P, Ostrosky-Zeichner L: Early antifungal intervention strategies in ICU patients. Curr Opin Crit Care 2010, 16:465-469.

31. Wey SB, Mori M, Pfaller MA, Woolson RF, Wenzel RP: Risk factors for hospital-acquired candidemia. A matched case-control study. Arch Intern Med 1989, 149:2349-2353.
32. Blumberg HM, Jarvis WR, Soucie JM, Edwards JE, Patterson JE, Pfaller MA, et al: Risk factors for candidal bloodstream infections in surgical intensive care unit patients: the NEMIS prospective multicenter study. The National Epidemiology of Mycosis Survey. Clin Infect Dis 2001, 33:177-186.

33. Saiman L, Ludington E, Dawson JD, Patterson JE, Rangel-Frausto S, Wiblin RT, et al: Risk factors for Candida species colonization of neonatal intensive care unit patients. Pediatr Infect Dis J 2001, 20:1119-1124.

34. Glocker EO, Hennigs A, Nabavi M, Schaffer AA, Woellner C, Salzer U, et al: A homozygous CARD9 mutation in a family with susceptibility to fungal infections. N Engl J Med 2009, 361:1727-1735.

35. Netea MG, Brown GD, Kullberg BJ, Gow NA: An integrated model of the recognition of Candida albicans by the innate immune system. Nat Rev Microbiol 2008, 6:67-78.

36. van de Veerdonk FL, Kullberg BJ, Netea MG: Pathogenesis of invasive candidiasis. Curr Opin Crit Care 2010, 16:453-459.

37. Kaposzta R, Tree P, Marodi L, Gordon S: Characteristics of invasive candidiasis in gamma interferon- and interleukin-4-deficient mice: role of macrophages in host defense against Candida albicans. Infect Immun 1998, 66:1708-1717.

38. Dupont H, Bourichon A, Paugam-Burtz C, Mantz J, Desmonts JM: Can yeast isolation in peritoneal fluid be predicted in intensive care unit patients with peritonitis? Crit Care Med 2003, 31:752-757.

39. Eggimann P, Francioli P, Bille J, Schneider R, Wu MM, Chapuis G, et al: Fluconazole prophylaxis prevents intra-abdominal candidiasis in highrisk surgical patients. Crit Care Med 1999, 27:1066-1072.

40. Sandven P, Qvist H, Skovlund E, Giercksky KE: Significance of Candida recovered from intraoperative specimens in patients with intraabdominal perforations. Crit Care Med 2002, 30:541-547.

41. Calandra T, Bille J, Schneider R, Mosimann F, Francioli P: Clinical significance of Candida isolated from peritoneum in surgical patients. Lancet 1989, 2:1437-1440.

42. Garbino J, Lew PD, Romand JA, Hugonnet S, Auckenthaler R, Pittet D: Prevention of severe Candida infections in non-neutropenic, high-risk, critically ill patients. A randomized, double-blind, placebo-controlled trial in SDD-treated patients. Intensive Care Med 2002, 28:1708-1717.

43. Pelz RK, Hendrix CW, Swoboda SM, Diener-West M, Merz WG, Hammond J, et al: Double-blind placebo controlled trial of fluconazole to prevent candidal infections in critically ill surgical patients. Ann Surg 2001, 233:542-548.

44. Prod'hom G, Bizzini A, Durussel C, Bille J, Greub G: Matrix-assisted laser desorption ionization-time of flight mass spectrometry for direct bacterial identification from positive blood culture pellets. J Clin Microbiol 2010, 48:1481-1483.

45. Prella M, Bille J, Pugnale M, Duvoisin B, Cavassini M, Calandra T, et al: Early diagnosis of invasive candidiasis with mannan antigenemia and antimannan antibodies. Diagn Microbiol Infect Dis 2005, 51:95-101.

46. Lamaris GA, Esmaeli B, Chamilos G, Desai A, Chemaly RF, Raad II, et al: Fungal endophthalmitis in a tertiary care cancer center: a review of 23 cases. Eur J Clin Microbiol Infect Dis 2008, 27:343-347.

47. Maertens J, Marchetti O, Herbrecht R, Cornely OA, Fluckiger U, Frere $P$, et al: European guidelines for antifungal management in leukemia and hematopoietic stem cell transplant recipients: summary of the ECIL 32009 update. Bone Marrow Transplant 2011, 46:709-718.

48. Karageorgopoulos DE, Vouloumanou EK, Ntziora F, Michalopoulos A Rafailidis PI, Falagas ME: beta-D-glucan assay for the diagnosis of invasive fungal infections: a meta-analysis. Clin Infect Dis 2011, 52:750-770.

49. Khot PD, Fredricks DN: PCR-based diagnosis of human fungal infections. Expert Rev Anti Infect Ther 2009, 7:1201-1221.

50. Avni T, Leibovici L, Paul M: PCR diagnosis of invasive candidiasis: systematic review and meta-analysis. J Clin Microbiol 2011, 49:665-670.

51. Fluckiger U, Marchetti O, Bille J, Eggimann P, Zimmerli S, Imhof A, et al: Treatment options of invasive fungal infections in adults. Swiss Med Wkly 2006, 136:447-463.

52. Petri MG, König J, Moecke HP, Gramm HJ, Barkow H, Kujath P, et al: Epidemiology of invasive mycosis in ICU patients: a prospective multicenter study in 435 non-neutropenic patients. Intensive Care Med 1997, 23:317-325.

53. Voss A, Hollis RJ, Pfaller MA, Wenzel RP, Doebbeling BN: Investigation of the sequence of colonization and candidemia in nonneutropenic patients. J Clin Microbiol 1994, 32:975-980. 
54. Rex JH, Walsh TJ, Sobel JD, Filler SG, Pappas PG, Dismukes WE, et al: Practice guidelines for the treatment of candidiasis. Infectious Diseases Society of America. Clin Infect Dis 2000, 30:662-678.

55. Vincent $J$, Anaissie E, Bruining $H$, Demajo W, el-Ebiary M, Haber J, et al: Epidemiology, diagnosis and treatment of systemic Candida infection in surgical patients under intensive care. Intensive Care Med 1998, 24:206-216.

56. Eggimann $\mathrm{P}$, Lamoth $\mathrm{F}$, Marchetti $\mathrm{O}$ : On track to limit antifungal overuse! Intensive Care Med 2009, 35:582-584.

57. Charles PE, Doise JM, Quenot JP, Haube H, Dalle F, Chavanet P, et al: Medical and surgical patients difference of outcome between Candidemia in critically ill patients. Intensive Care Med 2003, 29:2162-2169.

58. Piarroux R, Grenouillet F: Assessment of preemptive treatment to prevent severe candidiasis in critically-ill surgical patients. Crit Care Med 2004, 32(12):2443-9.

59. Agvald-Ohman C, Klingspor L, Hjelmqvist H, Edlund C: Invasive candidiasis in long-term patients at a multidisciplinary intensive care unit: Candida colonization index, risk factors, treatment and outcome. Scand J Infect Dis 2008, 40:145-153.

60. Senn L, Eggimann P, Ksontini R, Pascual A, Demartines N, Bille J, et al: Caspofungin for prevention of intra-abdominal candidiasis in high-risk surgical patients. Intensive Care Med 2009, 35(5):903-8.

61. Dubau B, Triboulet S, Winnock S: Utilisation pratique de I'index de colonisation. Ann Fr Anesth Reanim 2001, 20:418-420.

62. Chabasse D: Intérêt de la numération des levures dans les urines. Revue de la littérature et résultats préliminaires d'une enquête multicentrique réalisée dans 15 centres hospitaliers universitaires. Ann Fr Anesth Reanim 2001, 20:400-406.

63. Charles PE, Dalle F, Aube H, Doise JM, Quenot JP, Aho LS, et al: Candida spp. colonization significance in critically ill medical patients: a prospective study. Intensive Care Med 2005, 31:393-400.

64. Piarroux R, Grenouillet F, Balvay P, Tran V, Blasco V, Milloin M, et al: Assessment of preemptive treatment to prevent severe candidiasis in critically-ill surgical patients. Critical Care Med 2004, 32:2443-2449.

65. Normand S, Francois B, Darde ML, Bouteille B, Bonnivard M, Preux PM, et al: Oral nystatin prophylaxis of Candida spp. Colonization in ventilated critically-ill patients. Intensive Care Med 2005, 31:1466-1468.

66. Eggimann P, Garbino J, Pittet D: Management of Candida species infections in critically ill patient. Lancet Infect Dis 2003, 3:772-785.

67. DuPont H, Bourichon A, Paugam-Burtz C, Mantz J, Desmonts JM: Can yeast isolation in peritoneal fluid be predicted in intensive care unit patients with peritonitis? Critical Care Med 2003, 31:752-757.

68. Leon C, Ruiz-Santana S, Saavedra P, Almirante B, Nolla-Salas J, varezLerma F, et al: A bedside scoring system ("Candida score") for early antifungal treatment in nonneutropenic critically ill patients with Candida colonization. Crit Care Med 2006, 34:730-737.

69. Ostrosky-Zeichner L, Pappas PG, Shoham S, Reboli A, Barron MA, Sims C, et al: Improvement of a clinical prediction rule for clinical trials on prophylaxis for invasive candidiasis in the intensive care unit. Mycoses 2011, 54(1):46-51.

70. Leon C, Ruiz-Santana S, Saavedra P, Galvan B, Blanco A, Castro C, et al: Usefulness of the "Candida score" for discriminating between Candida colonization and invasive candidiasis in non-neutropenic critically ill patients: a prospective multicenter study. Crit Care Med 2009, 37:1624-1633.

71. Paphitou NI, Ostrosky-Zeichner L, Rex JH: Rules for identifying patients at increased risk for candidal infections in the surgical intensive care unit: approach to developing practical criteria for systematic use in antifungal prophylaxis trials. Med Mycol 2005, 43:235-243.

72. Ostrosky-Zeichner L, Sable C, Sobel J, Alexander BD, Donowitz G, Kan V, et al: Multicenter retrospective development and validation of a clinical prediction rule for nosocomial invasive candidiasis in the intensive care setting. Eur J Clin Microbiol Infect Dis 2007, 26:271-276.

73. Faiz S, Neale B, Rios E, Campos T, Parsley E, Patel B, et al: Risk-based fluconazole prophylaxis of Candida bloodstream infection in a medical intensive care unit. Eur J Clin Microbiol Infect Dis 2009, 28:689-692.

74. Ostrosky-Zeichner L, Aranah L, Eggimann P, Garbino J, Herbrecht R, Leon C, et al: Preliminary results of a multicenter, international, retrospective, study to validate a clinical prediction rule (CPR) to identify critically-il patients at risk of invasive candidiasis (IC) for TReatment with Empirical
Antifungal Therapy (TREAT Study). Abstracts of the 48th ICAAC, 20-22 October 2008, Chicago, IL

75. DiNubile MJ, Lupinacci RJ, Strohmaier KM, Sable CA, Kartsonis NA: Invasive candidiasis treated in the intensive care unit: observations from a randomized clinical trial. J Crit Care 2007, 22:237-244

76. Eggimann P, Calandra T, Fluckiger U, Bille J, Garbino J, Glauser M, et al: Invasive candidiasis: comparison of management choices by infectious disease and critical care specialists. Intensive Care Med 2005, 31:1514-1521.

77. Slotman GJ, Burchard KW: Ketoconazole prevents Candida sepsis in critically ill surgical patients. Arch Surg 1987, 122:147-151.

78. Savino JA, Agarwal N, Wry P, Policastro A, Cerabona T, Austria L: Routine prophylactic antifungal agents (clotrimazole, ketoconazole, and nystatin) in nontransplant/nonburned critically ill surgical and trauma patients. J Trauma 1994, 36:20-25.

79. Desai MH, Rutan RL, Heggers JP, Herndon DN: Candida infection with and without nystatin prophylaxis. A 11-year experience with patients with burn injury. Arch Surg 1992, 127:159-162.

80. Jacobs S, Price ED, Tariq M, Al Omar NF: Fluconazole improves survival in septic shock: a randomized double-blind prospective study. Crit Care Med 2003, 31:1938-1946.

81. He YM, LV YS, Ai ZL: Prevention and therapy of fungal infection in severe acute pancreatitis: a prospective clinical study. World J Gastroenterol 2003, 9:2619-2621.

82. Ables AZ, Blumer NA, Valainis GT, Godenick MT, Kajdasz DK, Palesch YY: Fluconazole prophylaxis of severe candida infection in trauma and postsurgical patients: a prospective, double-blind, randomized, placebocontrolled trial. Infect Dis Clin Pract 2000, 9:169-175.

83. Schuster MG, Edwards JE Jr, Sobel JD, Darouiche RO, Karchmer AW, Hadley S, et al: Empirical fluconazole versus placebo for intensive care unit patients: a randomized trial. Ann Intern Med 2008, 149:83-90.

doi:10.1186/2110-5820-1-37

Cite this article as: Eggimann et al:: Diagnosis of invasive candidiasis in the ICU. Annals of Intensive Care 2011 1:37.

\section{Submit your manuscript to a SpringerOpen ${ }^{\circ}$ journal and benefit from:}

- Convenient online submission

- Rigorous peer review

- Immediate publication on acceptance

- Open access: articles freely available online

- High visibility within the field

- Retaining the copyright to your article

Submit your next manuscript at $>$ springeropen.com 